\title{
EVOLUSI FOTOSINTESIS PADA TUMBUHAN
}

\author{
Nio Song $\mathbf{A i}^{(1)}$ \\ ${ }^{1)}$ Program Studi Biologi FMIPA, Universitas Sam Ratulangi \\ Jl. Kampus Unsrat Manado, 95115 \\ e-mail: nio_ai@yahoo.com
}

\begin{abstract}
ABSTRAK
Fotosintesis adalah proses sintesis karbohidrat dari bahan-bahan anorganik $\left(\mathrm{CO}_{2}\right.$ dan $\left.\mathrm{H}_{2} \mathrm{O}\right)$ pada tumbuhan berpigmen dengan bantuan energi cahaya matahari. Fotosintesis terdiri atas 2 fase, yaitu fase I yang berlangsung pada grana dan menghasilkan ATP dan $\mathrm{NADPH}_{2}$ serta fase II yang berlangsung pada stroma dan menghasilkan karbohidrat. Molekul air tidak dipecah dalam fotosintesis primitif dan setelah evolusi molekul air dipecahkan melalui 2 fotosistem sehingga $\mathrm{O}_{2}$ dilepaskan ke atmosfir. Fotosintesis berkembang menjadi lebih kompleks secara biokimia sampai terjadinya pemisahan antara respirasi dan fotosintesis beserta regulasinya. Evolusi tipe-tipe fotosintesis seperti $\mathrm{C}_{4}$ dan $\mathrm{CAM}$ merupakan akibat menurunnya rasio $\mathrm{CO}_{2} / \mathrm{O}_{2}$ dan radiasi yang intensif pada atmosfir.
\end{abstract}

Kata kunci: $\mathrm{C}_{3}, \mathrm{C}_{4}, \mathrm{CAM}$

\section{THE EVOLUTION OF PHOTOSYNTHESIS IN PLANT}

\begin{abstract}
Photosynthesis is the synthesis process of carbohydrate from inorganic materials $\left(\mathrm{CO}_{2}\right.$ dan $\left.\mathrm{H}_{2} \mathrm{O}\right)$ in plants with pigments using light energy. There are 2 phases of photosynthesis, i.e. phase I that occurs in grana and results in ATP dan $\mathrm{NADPH}_{2}$ and phase II that occurs in stroma and results in carbohydrate. The water molecule was not split apart in the primitive photosynthesis and after evolution the water molecule was oxidized via 2 photosystems, so that $\mathrm{O}_{2}$ was released to the atmosphere. Photosynthesis developed biochemically to be more complex until photosynthesis and its regulation was separated from respiration. The evolution of photosynthesis types, such as $\mathrm{C}_{4}$ and CAM, was resulted from the decrease of ratio $\mathrm{CO}_{2} / \mathrm{O}_{2}$ and the intensive radiation in the atmosphere.
\end{abstract}

Keywords: $\mathrm{C}_{3}, \mathrm{C}_{4}, \mathrm{CAM}$

\section{PENDAHULUAN}

Masa depan manusia sedikit banyak ditentukan oleh produksi bahan makanan, bahan bakar dan serat melalui proses fotosintesis. Proses sintesis karbohidrat dari bahan-bahan anorganik $\left(\mathrm{CO}_{2}\right.$ dan $\left.\mathrm{H}_{2} \mathrm{O}\right)$ pada tumbuhan berpigmen dengan bantuan energi cahaya matahari disebut fotosintesis dengan persamaan reaksi kimia berikut ini.

$$
6 \mathrm{CO}_{2}+6 \mathrm{H}_{2} \mathrm{O} \underset{\text { pigmen fotosintesis }}{\stackrel{\text { cahaya matahari }}{\longrightarrow}} \mathrm{C}_{6} \mathrm{H}_{12} \mathrm{O}_{6}+6 \mathrm{O}_{2}
$$

Berdasarkan reaksi fotosintesis di atas, $\mathrm{CO}_{2}$ dan $\mathrm{H}_{2} \mathrm{O}$ merupakan substrat dalam reaksi fotosintesis dan dengan bantuan cahaya matahari dan pigmen fotosintesis (berupa klorofil dan pigemen-pigmen lainnya) akan menghasilkan karbohidrat dan melepaskan oksigen. Cahaya matahari meliputi semua warna dari spektrum tampak dari merah hingga ungu, tetapi tidak semua panjang gelombang dari spektrum tampak diserap (diabsorpsi) oleh pigmen fotosintesis. Atom $\mathrm{O}$ pada karbohidrat berasal dari $\mathrm{CO}_{2}$ dan atom $\mathrm{H}$ pada karbohidrat berasal dari $\mathrm{H}_{2} \mathrm{O}$ (Sasmitamihardja dan Siregar, 1996).

Energi cahaya diubah menjadi energi kimia oleh pigmen fotosintesis yang terdapat pada membran interna atau tilakoid. Pigmen fotosintesis yang utama ialah klorofil dan karotenoid. Klorofil a dan b menunjukkan absorpsi yang sangat kuat untuk panjang gelombang biru dan ungu, jingga dan merah (lembayung) dan menunjukkan absorpsi yang sangat kurang untuk panjang gelombang 
hijau dan kuning hijau (500-600 nm) (Sasmitamihardja dan Siregar, 1996). Klorofil merupakan komponen kloroplas yang utama dan kandungan klorofil relatif berkorelasi positif dengan laju fotosintesis ( $\mathrm{Li}$ et al., 2006). Klorofil disintesis di daun dan berperan untuk menangkap cahaya matahari yang jumlahnya berbeda untuk tiap spesies. Sintesis klorofil dipengaruhi oleh berbagai faktor seperti cahaya, gula atau karbohidrat, air, temperatur, faktor genetik, unsur-unsur hara seperti $\mathrm{N}, \mathrm{Mg}, \mathrm{Fe}, \mathrm{Mn}, \mathrm{Cu}, \mathrm{Zn}, \mathrm{S}$ dan $\mathrm{O}$ (Hendriyani dan Setiari, 2009). Karotenoid menunjukkan absorpsi kuat untuk panjang gelombang biru dan ungu; memantulkan dan mentransmisikan panjang gelombang hijau, kuning, lembayung, merah (kombinasi warna-warna tersebut tampak kuning) (Sasmitamihardja dan Siregar, 1996).

$$
\text { Kompleks }
$$

protein-klorofil merupakan komponen fotosintesis yang penting (van der Mescht et al. 1999). Radiasi cahaya yang diterima oleh tanaman dalam fotosintesis diabsorbsi oleh klorofil dan pigmen tambahan yang merupakan kompleks protein-klorofil. Selanjutnya energi radiasi akan ditransfer ke pusat reaksi fotosistem I dan II yang merupakan tempat terjadinya perubahan energi cahaya menjadi energi kimia (Li et al., 2006). Dua mekanisme yang terlibat dalam pembentukan kompleks protein-klorofil adalah distribusi klorofil yang baru disintesis dan redistribusi klorofil yang sudah ada. Klorofil $b$ adalah hasil biosintesis dari klorofil a dan berperan penting dalam reorganisasi fotosistem selama adaptasi terhadap kualitas dan intensitas cahaya. Oleh sebab itu hilangnya klorofil a dan $b$ berpengaruh negatif terhadap efisiensi fotosintesis (van der Mescht et al., 1999).

Fotosintesis mengalami evolusi sehingga dikenal adanya tumbuhan $\mathrm{C}_{3}, \mathrm{C}_{4}$ dan CAM yang dapat diamati sebagai variasi dalam fotosintesis fase II atau reaksi fiksasi $\mathrm{CO}_{2}$. Tulisan ini akan menguraikan penggolongan tumbuhan $\mathrm{C}_{3}, \mathrm{C}_{4}$ dan CAM, proses evolusi fotosintesis yang berkaitan dengan perubahan kondisi atmosfir bumi berserta faktor-faktor lingkungan yang menguntungkan bagi keberadaan tumbuhan dengan tipe-tipe fotosintesis tersebut.

\section{TUMBUHAN $\mathrm{C}_{3}, \mathrm{C}_{4}$ DAN CAM}

Fotosintesis pada tumbuhan tingkat tinggi terdiri atas 2 fase (Sasmitamihardja dan Siregar, 1996; Wirahadikusumah, 1985), yaitu:

a. Fase I: reaksi fotokimia, reaksi fotolisis, reaksi Hill, reaksi fotofosforilasi, reaksi terang

Reaksi ini berlangsung di grana dan membutuhkan cahaya. Energi matahari ditangkap oleh pigmen penyerap cahaya dan diubah menjadi bentuk energi kimia, yaitu ATP dan senyawa pereduksi, yaitu $\mathrm{NADPH}$. Atom hidrogen dari molekul $\mathrm{H}_{2} \mathrm{O}$ dipakai untuk mereduksi $\mathrm{NADP}^{+}$ menjadi NADPH dan $\mathrm{O}_{2}$ dilepaskan sebagai hasil sampingan reaksi fotosintesis. Reaksi juga dirangkaikan dengan reaksi pembentukan ATP dari ADP dan Pi. Fase ini dapat ditulis sebagai persamaan reaksi:

$$
\begin{gathered}
\mathrm{H}_{2} \mathrm{O}+\mathrm{NADP}^{+}+\mathrm{ADP}+\mathrm{Pi} \stackrel{\text { energi matahari }}{\mathrm{O}_{2}+\mathrm{H}^{+}+\mathrm{NADPH}+\mathrm{ATP}} \\
\longrightarrow
\end{gathered}
$$

Pembentukan ATP dari ADP dan Pi merupakan mekanisme penyimpanan energi matahari yang diserap dan kemudian diubah menjadi energi kimia, sehingga fase ini disebut fotofosforilasi.

Fase I ini melibatkan 2 tipe kelompok pigmen fotosintesis, yaitu

1) Pigmen utama (pigmen primer, pusat reaksi): bentuk-bentuk klorofil a, seperti klorofil a $680\left(\mathrm{P}_{680}\right)$ dan klorofil a 700 $\left(\mathrm{P}_{700}\right)$,

2) Pigmen tambahan/pigmen antena (accessory pigment): berperan meneruskan energi cahaya ke pigmen utama, seperti klorofil a lainnya, klorofil b ( $\lambda$ 455-640 nm), karotenoid ( $\lambda$ 430-490 $\mathrm{nm})$

b. Fase II: reaksi termokimia, reaksi fiksasi/reduksi $\mathrm{CO}_{2}$, reaksi gelap

Reaksi ini berlangsung di stroma dan sering kali disebut reaksi gelap, karena reaksi ini dapat berlangsung tanpa adanya cahaya, walaupun tidak harus berlangsung dalam keadaan gelap. Hal ini disebabkan karena enzim-enzim stroma kloroplas tidak membutuhkan cahaya untuk aktivitasnya, tetapi membutuhkan ATP dan $\mathrm{NADPH}_{2}$. Fase II fotosintesis ini berlangsung pada stroma dan menghasilkan karbohidrat. Dalam reaksi ini senyawa kimia 
berenergi tinggi yang dihasilkan pada fase I, yaitu NADPH dan ATP dipakai untuk reaksi reduksi $\mathrm{CO}_{2}$ yang menghasilkan glukosa dengan persamaan reaksi:

$$
\begin{aligned}
& \mathrm{CO}_{2}+\mathrm{NADP}+\mathrm{H}^{+}+\mathrm{ATP} \longrightarrow \\
& \text { glukosa }+\mathrm{NADP}^{+}+\mathrm{ADP}
\end{aligned}+\mathrm{Pi}
$$

Ada 4 macam reaksi fiksasi $\mathrm{CO}_{2}$ (Sasmitamihardja dan Siregar, 1996), yaitu:

1) Daur $\mathrm{C}_{3}$ (daur Calvin)

Daur reaksi ini disebut daur $\mathrm{C}_{3}$ karena senyawa yang pertama kali dihasilkan adalah senyawa dengan 3 atom karbon yaitu asam fosfogliserat dari $\mathrm{CO}_{2}$; ribulosa-1,5-bifosfat dan $\mathrm{H}_{2} \mathrm{O}$. Tumbuhan yang melaksanakan daur tersebut disebut tumbuhan $\mathrm{C}_{3}$. Dalam daur ini satu molekul fosfogliseraldehida (PGAL) dibentuk dari fiksasi 3 molekul $\mathrm{CO}_{2}$. Reaksi keseluruhan adalah sebagai berikut:

$$
\begin{aligned}
& 3 \mathrm{CO}_{2}+9 \mathrm{ATP}+6 \mathrm{NADPH} \mathrm{NH}_{2} \rightarrow \\
& \quad \mathrm{PGAL}+9 \mathrm{ADP}+8 \mathrm{iP}+6 \mathrm{NADP}
\end{aligned}
$$

Selanjutnya PGAL akan diubah menjadi glukosa. Daur ini terjadi pada gandum, padi dan bambu.

2) Daur $\mathrm{C}_{4}$ (daur Hatch dan Slack)

Daur reaksi ini disebut daur $\mathrm{C}_{4}$ karena sebagian besar senyawa yang pertama kali dihasilkan adalah senyawa dengan 4 atom karbon yaitu asam malat dan asam aspartat dan tumbuhan yang melaksanakan daur tersebut disebut tumbuhan $\mathrm{C}_{4}$. Yang termasuk tumbuhan $\mathrm{C}_{4}$ adalah beberapa spesies Gramineae di daerah tropis termasuk jagung, tebu, sorghum. Anatomi daun tumbuhan $\mathrm{C}_{4}$ unik yang dikenal dengan anatomi Kranz, yaitu terdapat sel-sel seludang parenkim yang mengelilingi ikatan pembuluh dan memisahkannya dengan sel-sel mesofil. Pada tumbuhan $\mathrm{C}_{4}$ terdapat pembagian kerja antara selsel mesofil dan sel-sel seludang parenkim, yaitu pembentukan asam malat dan aspartat dari $\mathrm{CO}_{2}$ terjadi di sel-sel mesofil, sedangkan daur Calvin berlangsung di sel-sel seludang parenkim.

3) Daur CAM (Crassulacean Acid Metabolism)

Daur CAM merupakan fiksasi $\mathrm{CO}_{2}$ pada spesies sukulen anggota famili Crassulaceae (misalnya kaktus, nenas) yang hidup di daerah kering, mempunyai daun tebal dengan rasio permukaan terhadap volume rendah, laju transpirasi rendah, sel-sel daun mempunyai vakuola relatif besar dan lapisan sitoplasma yang tipis. Fiksasi yang menghasilkan asam malat terjadi pada malam hari pada saat stomata terbuka dan daur Calvin yang menghasilkan glukosa terjadi pada siang hari pada saat stomata tertutup. Jadi fiksasi $\mathrm{CO}_{2}$ pada tumbuhan CAM mirip dengan tumbuhan $\mathrm{C}_{4}$, perbedaannya pada tumbuhan $\mathrm{C}_{4}$ terjadi pemisahan tempat sedangkan pada tumbuhan CAM terjadi pemisahan waktu.

Kemampuan tumbuhan melaksanakan daur CAM ditentukan secara genetis, tetapi kemampuan ini juga dikontrol oleh lingkungan. Umumnya CAM berlangsung lebih cepat pada siang hari yang panas dengan tingkat cahaya yang tinggi dan malam hari yang dingin dan tanah yang kering seperti di gurun. Fiksasi $\mathrm{CO}_{2}$ pada beberapa tumbuhan CAM dapat beralih ke daur $\mathrm{C}_{3}$ setelah hujan atau suhu malam hari yang lebih tinggi daripada biasanya karena stomata terbuka lebih lama pada pagi hari (Campbell et al., 2006).

Penggolongan tumbuhan menjadi tumbuhan $\mathrm{C}_{3}$ dan $\mathrm{C}_{4}$ adalah didasarkan pada senyawa yang diubah dari $\mathrm{CO}_{2}$ pada fase II dari fotosintesis (reaksi fiksasi atau reduksi $\mathrm{CO}_{2}$ ). Pada tumbuhan $\mathrm{C}_{3}, \mathrm{CO}_{2}$ diubah menjadi senyawa $\mathrm{C}_{3}$ yaitu asam 3fosfogliserat yang selanjutnya akan diubah menjadi glukosa.

$$
\begin{gathered}
\text { Ribulosa-1,5-bifosfat }-\mathrm{CO}_{2}+\mathrm{H}_{2} \mathrm{O} \\
\text { Enzim rubisco } \\
\text { 3-fosfogliserat }+3 \text {-fosfogliserat }
\end{gathered}
$$

Sedangkan pada tumbuhan $\mathrm{C}_{4}, \mathrm{CO}_{2}$ diubah menjadi senyawa $\mathrm{C}_{4}$ yaitu asam oksaloasetat yang selanjutnya diubah menjadi asam malat dan asam aspartat.

$$
\begin{gathered}
\text { Fosfoenol piruvat }-\mathrm{CO}_{2}+\mathrm{H}_{2} \mathrm{O} \\
\text { fosfoenolpiruvat } \\
\text { karboksilase } \\
\text { asam oksaloasetat }
\end{gathered}
$$


$\mathrm{NADPH}_{2} \quad \mathrm{NAD}^{+}$

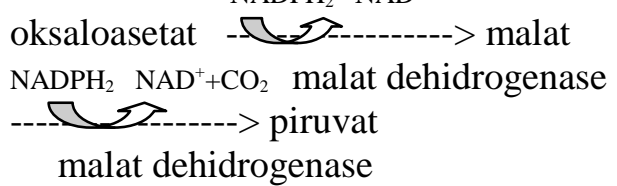
piruvat dikinase
oksaloasetat ----------------> aspartat
(dioksidasi menghasilkan $\mathrm{CO}_{2}$ untuk daur $\mathrm{C}_{3}$ )

4) Daur $\mathrm{C}_{2}$ (daur glikolat atau fotorespirasi) Selain bereaksi dengan $\mathrm{CO}_{2}$, enzim ribulosa bifosfat karboksilase yang mengkatalisis pembentukan fosfogliserat dalam daur $\mathrm{C}_{3}$, juga dapat bereaksi dengan $\mathrm{O}_{2}$, sehingga pada kondisi demikian enzim ini disebut ribulosa bisfosfat oksigenase. Aktivitas ribulosa bifosfat oksigenase adalah mengubah satu molekul ribulosa bifosfat menjadi satu molekul asam fosfoglikolat dan satu molekul asam fosfogliserat, bukan menjadi dua molekul asam fosfogliserat jika $\mathrm{CO}_{2}$ yang difiksasi. Dengan demikian digunakan nama enzim rubisco (ribulosa bifosfat karboksilase oksigenase) untuk menyatakan keterlibatan enzim tersebut dalam fiksasi $\mathrm{CO}_{2}$ dan $\mathrm{O}_{2}$. Ada 4 hal penting yang perlu diperhatikan dalam jalur glikolat, yaitu:

a) Jalur glikolat terjadi pada 3 tempat, yaitu kloroplas, peroksisom dan mitokondria.

b) Reaksi oksidasi ini membentuk glikolat dan produk sampingan $\mathrm{H}_{2} \mathrm{O}_{2}$ dan oksidan kuat yang beracun ini diuraikan oleh katalase dalam peroksisom.

c) Asam amino glisin dan serin dihasilkan.

d) Satu molekul $\mathrm{CO}_{2}$ dihasilkan dan satu molekul $\mathrm{O}_{2}$ diserap untuk tiap dua molekul glikolat yang dioksidasi. Oleh sebab itu daur glikolat disebut juga fotorespirasi karena terjadi pengambilan $\mathrm{O}_{2}$ dan pembentukan $\mathrm{CO}_{2}$ oleh jaringan yang berfotosintesis pada saat ada cahaya (Sasmitamihardja dan Siregar, 1996).

\section{EVOLUSI FOTOSINTESIS}

Bukti-bukti geologis untuk evolusi fotosintesis sangat sedikit, karena fotosintesis merupakan proses biokimia yang melibatkan protein dan molekul-molekul organik lain yang cepat mengalami dekomposisi.
Hipotesis tentang perkembangan evolusi fotosintesis dikemukakan oleh Schopf (1978) dalam Lawlor (1993) dan Bendall (1986) dalam Lawlor (1993). Bumi terbentuk kirakira 4,6 x $10^{9}$ tahun yang lalu (Gambar 1) dan untuk $0,5 \times 10^{9}$ tahun pertama bumi menjadi dingin dan memadat. Jarak bumi dari matahari dan ukuran bumi menentukan panas yang diterima dan gaya yang menahan gas di permukaan, sehingga air dan atmosfir tetap ada di bumi. Atmosfir primitif sangat tereduksi dan mengandung metana $\left(\mathrm{CH}_{4}\right), \mathrm{H}_{2}$, $\mathrm{H}_{2} \mathrm{~S}, \mathrm{CO}_{2}, \mathrm{NH}_{3}$ dan lain-lain, tetapi tidak mengandung $\mathrm{O}_{2}$ atau terdapat dalam kondisi anoksia (Lawlor, 1993).

Kondisi tanpa $\mathrm{O}_{2}$ ini sangat penting untuk evolusi kehidupan karena $\mathrm{O}_{2}$ merusak molekul-molekul organik. Atmosfir bumi primitif juga tidak mengandung ozon yang merupakan lapisan tipis di atmosfir bagian atas dan berfungsi untuk menyerap sinar ultra violet (UV). Radiasi, temperatur tinggi dan berbagai macam gas yang terlibat dalam aktivitas vulkanik, memungkinkan terjadinya sintesis molekul-molekul organik. Cara kerja sistem biologi yang memperbanyak diri pada kondisi tersebut belum banyak diketahui. Tetapi fakta menunjukkan adanya organisme dengan ukuran dan struktur sel yang mirip dengan bakteri pada batuan yang berumur 3,5 $\mathrm{x} 10^{9}$ tahun. Sejenis metabolisme yang melibatkan cahaya mungkin berlangsung pada masa itu karena derivat karotenoid terdeteksi pada batuan di zaman tersebut. Kemungkinan organisme primitif tersebut mensintesis ATP dengan proton yang digerakkan oleh cahaya seperti halnya pada bakteri Halobacterium halobium. Karbon organik dari deposit pada masa tersebut menunjukkan diskriminasi terhadap isotop ${ }^{13} \mathrm{C}$ dan hal ini membuktikan bahwa fotosintesis terjadi pada awal evolusi. Organisme tersebut mampu menyediakan ATP sendiri dengan mengeksploitasi sumber energi yang berlimpah (Lawlor, 1993). 


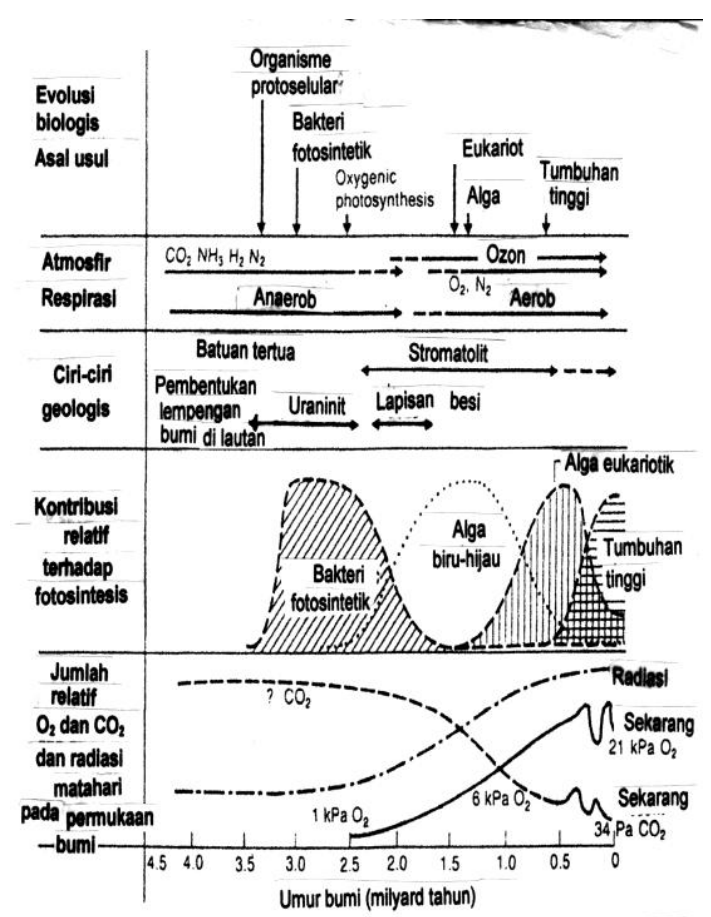

Gambar 1. Skema kemungkinan urutan peristiwa evolusi fotosintesis dan hubungannya dengan beberapa proses geologis dan biologis lainnya
Beberapa proses dikaitkan dengan reaksi terang (fase I fotosintesis) dan aliran elektron serta ATP termasuk asimilasi $\mathrm{N}_{2}$, $\mathrm{CO}_{2}$ dan S. Tetapi molekul air tidak dipecah dalam fotosintesis primitif tersebut sampai $3,5 \times 10^{9}$ tahun yang lalu, sehingga tidak ada $\mathrm{O}_{2}$ yang dihasilkan dalam fotosintesis dan atmosfir tereduksi. Setelah terjadinya evolusi proses pemecahan molekul air yang memerlukan energi cahaya melalui 2 fotosistem, air dapat teroksidasi dan $\mathrm{O}_{2}$ dilepaskan ke atmosfir. Banyak bukti mendukung skala waktu evolusi untuk proses ini (Schopf 1978 dalam Lawlor 1993). Lapisan kapur fosil yang tebal dan disebut stromatolit, dibentuk $3 \times 10^{9}$ tahun yang lalu dan mengandung alga biru hijau yang juga ditemukan pada stromatolit masa kini. Tetapi produksi $\mathrm{O}_{2}$ mungkin sudah terjadi sebelumnya. Beberapa proses geokimia juga mungkin mengkonsumsi $\mathrm{O}_{2}$, misalnya ion ferro $\left(\mathrm{Fe}^{2+}\right)$ menghasilkan $\mathrm{Fe}_{3} \mathrm{O}_{2}$ yang tidak larut. Kandungan $\mathrm{Fe}^{2+}$ di lautan mungkin menipis karena deposisi bijih besi. Proses ini mengakibatkan terbentuknya lapisan merah dalam waktu $2,2 \times 10^{9}-1,7 \times 10^{9}$ tahun yang lalu. Oksigen yang dihasilkan oleh pemecahan molekul $\mathrm{H}_{2} \mathrm{O}$ oleh sinar UV terlalu sedikit untuk memungkinkan terjadinya penurunan $\mathrm{Fe}^{2+}$ yang drastis. Uraninit $\left(\mathrm{UO}_{2}\right)$ adalah bijih uranium yang tidak larut dalam kondisi dengan konsentrasi $\mathrm{O}_{2}$ di atas $1 \%$ dan deposit $\mathrm{UO}_{2}$ yang berumur lebih muda dari $2 \times 10^{9}$ tahun yang lalu tidak ditemukan. Jadi, antara $3,5 \times 10^{9}$ dan 3,0 x $10^{9}$ tahun yang lalu fotosintesis berkembang dengan menggunakan $\mathrm{H}_{2} \mathrm{O}$ sebagai reduktan dan $\mathrm{O}_{2}$ di atmosfir meningkat (Lawlor, 1993).

Deposisi karbon yang tereduksi mungkin berperan dalam penurunan kandungan karbon dan peningkatan $\mathrm{O}_{2}$ di atmosfir. Pada zaman tersebut konsentrasi $\mathrm{CO}_{2}$ mungkin beberapa ratus kali lebih besar daripada saat ini. Sampai dengan $1,5 \times 10^{9}-$ $1,0 \times 10^{9}$ tahun yang lalu, kondisi bumi mulai bersifat aerob karena buffer kimia habis terpakai dan tekanan $\mathrm{O}_{2}$ lebih dari $1 \mathrm{kPa}$. Oksigen di atmosfir bagian atas membentuk lapisan ozon yang menyerap radiasi ultra violet, sehingga terjadi evolusi organisme tingkat tinggi dan kehidupan di darat dimulai. $\mathrm{O}_{2}$ meningkatkan jumlah energi untuk respirasi sebanyak 10 kali lipat dengan cara berperan sebagai reseptor terminal untuk proses fotosintesis. Sebagian besar organisme yang hidup saat ini, termasuk manusia, tergantung pada $\mathrm{O}_{2}$ yang diproduksi dalam proses fotosintesis (Lawlor, 1993).

Eukariot yang terdiri dari sel-sel bernukleus, mungkin berkembang dalam kehidupan bumi tahap awal, berdasarkan bukti adanya steran (molekul-molekul turunan sterol yang diperkirakan hanya dibuat oleh sel-sel bernukleus seperti eukariot) di batuan pada $1,7 \times 10^{9}$ tahun yang lalu. Eukariot ini berkembang pesat sejak $1 \times 10^{9}$ tahun yang lalu dan membentuk organismeorganisme makroskopis dan multinukleat (baik tumbuhan maupun hewan). Proses perkembangan ini mungkin berkaitan dengan perubahan iklim sekitar 900-600 juta tahun yang lalu akibat aktivitas tektonik dan vulkanik, hilangnya sejumlah besar karbon dengan terkubur sebagai sedimen serta dimulainya perubahan iklim global termasuk terbentuknya sungai es. Bukti dari struktur dan fungsi asam nukleat pada kloroplas dan mitokondria tumbuhan tingkat tinggi menunjukkan bahwa organel-organel ini merupakan bakteri dan alga hijau biru yang masuk ke dalam sel-sel eukariotik yang tidak berfotosintesis (Lawlor, 1993).

Fotosintesis berkembang menjadi lebih kompleks secara biokimia dan terjadi 
pemisahan antara respirasi dan fotosintesis beserta regulasinya. Fotosintesis membentuk biosfir baik secara langsung maupun melalui pengaruhnya pada iklim dan geologi bumi. Unsur karbon dari fotosintesis menyusun minyak, batu bara dan gas, sehingga $\mathrm{CO}_{2}$ di atmosfir menurun dan rasio $\mathrm{O}_{2} / \mathrm{CO}_{2}$ meningkat. Kondisi ini mungkin tidak menguntungkan bagi fotosintesis karena enzim ribulosa bifosfat karboksilase yang mengfiksasi $\mathrm{CO}_{2}$ bekerja kurang efisien. Di daratan hilangnya air dari tumbuhan yang dicegah dengan adanya kutikula yang tebal, juga mengurangi persediaan $\mathrm{CO}_{2}$. Evolusi tipe-tipe fotosintesis seperti $\mathrm{C}_{4}$ dan CAM mungkin merupakan respons terhadap menurunnya rasio $\mathrm{CO}_{2} / \mathrm{O}_{2}$ dan atmosfir yang lebih kering dengan radiasi yang intensif. Aktivitas manusia pada saat ini meningkatkan konsentrasi $\mathrm{CO}_{2}$ di atmosfir dengan membakar bahan bakar fosil (Lawlor, 1993). Hal ini mungkin memperbaiki pertumbuhan tumbuhan dalam waktu singkat dan juga akan mempengaruhi iklim dunia.

\section{EVOLUSI DAN DISTRIBUSI TUMBUHAN $\mathrm{C}_{4}$}

Tumbuhan tingkat tinggi yang ada di bumi terdiri dari $5 \%$ tumbuhan $\mathrm{C}_{4}, 85 \%$ tumbuhan $\mathrm{C}_{3}$ dan $10 \%$ tumbuhan CAM. Fotosintesis $\mathrm{C}_{4}$ pertama kali ditemukan pada rumput-rumputan 24-35 tahun yang lalu dan pada tumbuhan dikotil 15-21 juta tahun yang lalu. Konsentrasi $\mathrm{CO}_{2}$ di udara yang menurun sangat berpengaruh terhadap evolusi tumbuhan $\mathrm{C}_{4}$. Penurunan konsentrasi $\mathrm{CO}_{2} \mathrm{di}$ udara disebabkan oleh aktivitas fotosintesis dan perubahan tektonik yang diikuti oleh perubahan geokimia. Tabrakan daratan India mengakibatkan terangkatnya Plateau Tibet, sehingga bagian kerak bumi yang terpapar pada udara bebas menjadi lebih luas. Reaksi kimia yang terjadi pada kerak bumi ialah $\mathrm{CaSiO}_{3}+\mathrm{CO}_{2} \longleftrightarrow \mathrm{CaCO}_{3}+\mathrm{SiO}_{2}$. Reaksi ini menyebabkan penurunan konsentrasi $\mathrm{CO}_{2}$ di udara yang menyolok dan kondisi ini menguntungkan bagi tumbuhan $\mathrm{C}_{4}$ (Lambers et al., 2008).

Beberapa hal penting dalam proses pengikatan $\mathrm{CO}_{2}$ pada tumbuhan $\mathrm{C}_{4}$ dibandingkan dengan tumbuhan $\mathrm{C}_{3}$ (Lambers et al. 2008) adalah sebagai berikut:

1. Membutuhkan lebih banyak ATP,
2. Sintesis glukosa berlangsung lebih luas per satuan luas daun,

3. Berlangsung lebih efisien dalam keadaan intensitas cahaya yang tinggi,

4. Afinitas enzim fosfoenolpiruvat karboksilase yang besar terhadap $\mathrm{CO}_{2}$,

5. Proses fotosintesis dapat berlangsung dengan cukup baik pada saat konsentrasi $\mathrm{CO}_{2}$ yang sangat sedikit di udara,

6. Tidak terjadi atau sedikit sekali terjadi fotorespirasi (pernafasan dalam keadaan terang di kloroplas).

Enzim rubisco tidak dapat bekerja secara efisien pada saat konsentrasi $\mathrm{CO}_{2}$ yang rendah dan konsentrasi $\mathrm{O}_{2}$ yang tinggi di udara. Konsentrasi $\mathrm{CO}_{2}$ yang rendah di udara akan meningkatkan fotorespirasi yang lebih banyak terjadi pada tumbuhan $\mathrm{C}_{3}$. Keadaan ini menguntungkan untuk perkembangan tumbuhan $\mathrm{C}_{4}$. Bukti-bukti morfologi, ekogeografi dan molekular (analisis urutan nukleotida yang mengkode subunit glisin dekarboksilase) menunjukkan bahwa tumbuhan $\mathrm{C}_{4}$ berkembang dari tumbuhan $\mathrm{C}_{3}$ melalui evolusi konvergen (Lambers et al., 2008)

Di samping konsentrasi $\mathrm{CO}_{2}$ yang rendah di udara, faktor-faktor lingkungan lain juga menentukan evolusi dan distribusi tumbuhan $\mathrm{C}_{4}$. Analisis komposisi karbon isotop pada komponen lapisan lilin daun menunjukkan bahwa iklim regional menentukan kepadatan relatif tumbuhan $\mathrm{C}_{3}$ dan $\mathrm{C}_{4}$. Faktor-faktor lingkungan yang dimaksud antara lain daerah kering dengan latituda (garis lintang) rendah, temperatur tinggi dengan kondisi kering dan kadar garam tinggi akibat pemanasan global dan kebakaran. Tumbuhan $\mathrm{C}_{4}$ banyak ditemukan di daerah tropis dengan altituda rendah (ketinggian dari permukaan laut), padang rumput di dataran rendah baik di daerah tropis maupun daerah temperata dengan curah hujan tinggi di musim panas (Lambers et al. 2008).

Tidak seperti halnya tumbuhan $\mathrm{C}_{3}$, tumbuhan $\mathrm{C}_{4}$ tumbuh subur di di ekosistem yang terbuka dengan temperatur tinggi. Hal ini disebabkan karena enzim rubisco pada tumbuhan $\mathrm{C}_{3}$ akan lebih banyak berikatan dengan $\mathrm{O}_{2}$ daripada dengan $\mathrm{CO}_{2}$, sehingga terjadi fotorespirasi dan mengurangi atau menghambat reaksi fiksasi atau reduksi $\mathrm{CO}_{2}$. Kondisi ini akan mengakibatkan laju 
fotosintesis menurun. Sebaliknya tumbuhan $\mathrm{C}_{4}$ tidak berproduksi optimal di daerah beriklim dingin. Hal ini disebabkan karena enzim piruvat dikinase (enzim penting dalam lintas $\mathrm{C}_{4}$ ) sangat sensitif terhadap temperatur rendah. Compatible solutes (solut yang tidak mengganggu metabolisme sel pada konsentrasi yang tinggi) dapat menurunkan sensitivitas enzim tersebut terhadap temperatur rendah, sehingga memungkinkan penyebaran tumbuhan $\mathrm{C}_{4}$ ke daerah temperata di masa mendatang. Akan tetapi peningkatan konsentrasi $\mathrm{CO}_{2}$ di udara akhir-akhir ini akan menguntungkan kelangsungan hidup tumbuhan $\mathrm{C}_{3}$ (Lambers et al. 2008).

\section{KESIMPULAN}

1. Evolusi fotosintesis dimulai dengan tidak dipecahnya molekul air dan tanpa pelepasan oksigen sampai dengan terjadinya pemisahan antara fotosintesis dan respirasi.

2. Evolusi tipe-tipe fotosintesis seperti $\mathrm{C}_{4}$ dan CAM merupakan respons terhadap menurunnya rasio $\mathrm{CO}_{2}$ dan $\mathrm{O}_{2}$ dan kondisi atmosfir dengan radiasi yang intensif.

3. Tumbuhan $\mathrm{C}_{4}$ berkembang dari tumbuhan $\mathrm{C}_{3}$ melalui evolusi konvergen yang dipengaruhi oleh rendahnya konsentrasi $\mathrm{CO}_{2}$ di atmosfir, latituda, altituda, temperatur dan kadar garam.

4. Konsentrasi $\mathrm{CO}_{2}$ di atmosfir yang meningkat akhir-akhir ini menguntungkan tumbuhan $\mathrm{C}_{3}$.

5. Fiksasi $\mathrm{CO}_{2}$ pada beberapa tumbuhan CAM dapat berubah menjadi tumbuhan $\mathrm{C}_{3}$ setelah hujan atau temperatur lingkungan yang tinggi pada malam hari.

\section{DAFTAR PUSTAKA}

Campbell, N.A., J.B. Reece \& L.G. Mitchell. 2006. Biology. Concepts \& Connections. 5th Ed. Addison Wesley Longman Inc. pp 118.

Lambers, H., T.L. Pons \& F.S. Chapin III. 2008. Plant Physiological Ecology. 2nd Ed. Springer Science + Bussiness Media LLC. New York. USA. pp 7375.
Lawlor, D.W. 1993. Photosynthesis: Molecular, Physiological and Environmental Processes. 2nd Ed. Longman Scientific \& Technical. England. pp 12-15.

Sasmitamihardja, D. and A.H. Siregar. 1996. Fisiologi Tumbuhan. Proyek Pendidikan Akademik Dirjen Dikti. Depdikbud. Bandung. pp 253-281.

Wirahadikusumah, M. 1985. Biokimia: metabolisme, energi, karbohidrat, dan lipid. Penerbit ITB. Bandung. pp 96118.

Hendriyani, I.S. and N. Setiari. 2009. Kandungan klorofil dan pertumbuhan kacang panjang (Vigna sinensis) pada tingkat penyediaan air yang berbeda. $J$. Sains \& Mat. 17 (3):145-150.

Li, R., P. Guo, M. Baum, S. Grando and S. Ceccarelli. 2006. Evaluation of chlorophyll content and fluorescence parameters as indicators of drought tolerance in barley. Agric. Sci. in China 5 (10):751-757.

Van der Mescht, A., J.A. de Ronde \& F.T. Rossouw. 1999. Chlorophyll fluorescence and chlorophyll content as a measure of drought tolerance in potato. South African J. of Sci. 95:407412. 